Takaharu Oda

Trinity College Dublin, Ireland

ORCID: 0000-0001-7465-6449

e-mail: odat@tcd.ie

\title{
Berkeley on Voluntary Motion: A Conservationist Account
}

DOI: http://dx.doi.org/10.12775/RF.2018.039

\section{Introduction}

Suppose you decide to raise your arm. Who is the agent that wills and brings about the movement? - Is that you in reality? In this article, I will critically evaluate Bishop George Berkeley's (1685-1753) argument of voluntary motion in human body parts. Rather than internal organs, by 'human body parts' I mean the parts of the body that are movable by muscles, such as limbs and eyelids, under the voluntary control of one's mind. In his early days (1707-1708), Berkeley spelt out that 'We move our Legs our selves. 'tis we that will their movement' (Notebooks 548). ${ }^{1}$ Do our minds, then, really bring about the movements in our body parts? -

1 With the exception of Notebooks, I reference Berkeley's text from the LuceJessop edition. The following abbreviations are used: Notebooks $\mathrm{x}$ for Notebooks (also known as Philosophical Commentaries), entry x (the Thomas-Luce edition); Principles $\mathrm{x}$ for Part I of A Treatise concerning the Principles of Human Knowledge, section $\mathrm{x}$ (Works II); Dialogues x:y for Three Dialogues between Hylas and Philonous, dialogue x, page y (Works II); Correspondence 1729/30:x for Philosophical Correspondence between Berkeley and Samuel Johnson 1729-30, section x (Works II); Alciphron x:y for Alciphron, or the Minute Philosopher, dialogue x, section y (Works III); De motu x for De motu sive de motus principio E natura, et de causa communicationis motuum, section x (Works IV, Luce's translation); Siris x for Siris: A Chain of Philosophical Reflexions and Inquiries, section $\mathrm{x}($ Works $\mathrm{V})$. Berkeley's original emphasis is in italics, unless otherwise indicated. 
Or does God do so? When we decide to move our legs, our minds seem to cause the subsequent bodily motions. However, is such mind-body causation at all possible? Parsing out this human problem in relation to the divine cause, I will divide the interpretations of Berkeley commentators into two types. Firstly, many commentators read Berkley as claiming that God always moves our legs, on behalf of our wills to do so. Yet, secondly, others contend that humans do have the volitional, causal power to move our own legs. I will argue that the second and literal interpretation dovetails more consistently with Berkeley's original suggestion.

The first type of interpretation (by Jolley, Taylor, Bennett, et al. ${ }^{2}$ is a version of occasionalism. This is a doctrine that allows for no causal power of finite minds/spirits, but only that of God. On this occasionalist reading, even if we have our own will, God brings about the (effects/ideas of) movements in our legs because God is regarded as the first and single cause that brings about physical effects on the occasion of our volitions. The second type (in which I include Roberts, Stoneham, and Fleming) ${ }^{3}$ is a version of conservationism, as an alternative interpretation to the occasionalist reading. ${ }^{4}$ I will side with the conservationist reading, according to which finite minds directly or immediately cause the motions in their body parts at will under God's sustenance of the existence and properties of their bodies. ${ }^{5}$ This reading is conducive to a sense of realism

2 Jolley 1990; Taylor 1985; Bennett 2001.

3 Roberts 2007; 2010; Stoneham 2002; 2010; forthcoming; Fleming 2006.

4 One might rather consider three scholastic types of reading. See McDonough 2008, 568-72; Schmaltz 2008, 16-19, 36-44; Freddoso 1988, 77-78, 104; 1991, 553-555; 1994, 132-135. Besides 'mere conservationism' (in Freddoso's term) and 'occasionali$\mathrm{sm}^{\prime}$, the third reading is called 'concurrentism' (causal compatibilism or creaturely action working together with God), embraced by popular scholastics such as Thomas Aquinas (1225-1274) and Francisco Suárez (1548-1617). According to the doctrine, Berkeley may hold mind-body causation that the primary divine cause and secondary causes (or finite minds) co-operate to will and thereby bring about the effects (ideas) of bodily motions. However, I aim to show that the third concurrentist reading can be sufficiently subsumed under the non-occasionalist or conservationist reading of the creaturely voluntary motion. This is because I read Berkeley as arguing that human minds have the secondary but immediate causes insofar as we direct and move our own body parts, even under the first but distant divine cause. This does not necessarily amount to an accurate concurrence between the minds of God and humans, putting aside two premises of the divine creation and conservation. See also Stoneham forthcoming, 4-5, nn. 5, 7; Frankel 2015, 105, 113, n. 16.

5 On (mere) conservationism, Berkeley's Correspondence to his American disciple, Samuel Johnson, ought to be examined (1729:3): 'the divine conservation of things is equipollent to, and in fact the same thing with, a continued creation ... and Durandus ... held the world to be a machine like a clock, made and put in motion by God, but afterwards continuing to go of itself, was therein particular, and had few followers. ... all nature would shrink to nothing, if not upheld and preserved in being by the same force that first created it. This I am sure is agreeable to Holy Scripture'. On the 
regarding mind-body causation by our own acts of volition, somehow independent of the divine mind. By interpreting (i) theodicy and (ii) an account of influencing other minds in line with the conservationist reading, I will take a further step in also considering (iii) the existence of an improper but necessary directing principle in the faculty of finite minds. From these three perspectives, I will argue that Berkeley is a conservationist, rather than an occasionalist, with regard to mind-body causation by human agency to the extent of moving body parts.

This article is accordingly broken down into three sections. §I briefly presents what occasionalism is and then explains the occasionalist reading of voluntary motion in Berkeley. §II, by contrast, elaborates on the alternative possibility of the non-occasionalist or conservationist reading. Finally, §III evaluates the two interpretations by comparing their merits, and argues why the conservationist reading is more successful than the occasionalist one.

\section{Occasionalism}

On the whole, the commentaries divide into two types of reading: (1) the occasionalist reading and (2) the non-occasionalist or conservationist reading. In fact, many of the commentators read Berkeley's argument of voluntary motion from an occasionalist viewpoint, i.e. attributing no causal power to human minds but only to the divine mind. This I call the occasionalist reading of human voluntary motion in body parts, such as limbs. Considering some striking points in Berkeley, this section will first review that reading.

Since the early stage of his career, Berkeley had been criticised for his doctrinal affinity with the occasionalism of Père Nicolas de Malebranche (1638-1715). ${ }^{6}$ In effect, right after his early publications (1709-1713,

mechanical example of 'the clockwork of Nature' and 'watchmaker', see Principles 60-62. Siding with the Works II editor, T.E. Jessop, I read Berkeley as explaining the view of an unpopular scholastic philosopher, bishop Durandus de Saint-Pourçain (c.1270-1334). Furthermore, in my view, it may be the case that Berkeley himself, as one of his 'few followers', conceded Durandus' conservationism in terms of the creaturely voluntary motion which is not immediately caused by God. In other words, creatures are held liable for the immediate voluntary motions in their body parts. As for Durandus' (and other scholastics') conservationism, see Freddoso 1991, 555; 1994, 142-151; Schmaltz 2008, 19-24; Frost 2014, 656-658, n. 4.

6 Occasionalism has been associated with theological tenets of e.g. Abu Hamid al-Ghazali (1058-1111) and Solomon ibn Gabirol (c.1021-c.58) in the Middle Ages, deriving from Neoplatonic roots. Their versions of occasionalism precede the seventeenth-century occasionalism of e.g. Claude Clerselier (1614-1684), Louis de la Forge (1632-1666), and Malebranche. See Schmaltz 2008, 9-16, 121-124; Richmond 2009, 89-90; Freddoso 1988, 76-79. 
such as Principles, Passive Obedience, and Dialogues), Berkeley came to be seen as a Malebranchean occasionalist; he was labelled a Malebranchiste de bonne foi in the French Jesuit academic journal, Mémoires des Trévoux (1713). ${ }^{7}$ Commentators have since paid considerable attention to the similarities between the two philosophers, claiming that Berkeley was an occasionalist or Malebranchist to a certain or great degree. ${ }^{8}$

In the first place, I shortly introduce Malebranche's occasionalism, for Berkeley himself was concerned about the alleged affinity with that. ${ }^{9}$ As an occasionalist, Malebranche held that God's volitional power was the only true cause for the existence of creatures in nature, as follows: ${ }^{10}$

there is only one true cause because there is only one true God; that the nature or power of each thing is nothing but the will of God; that all natural causes are not true causes but only occasional causes.

7 Bracken 1965, 16.

8 Berkeley might be portrayed as part of the occasionalist development, as Bardout $(2002,492)$ explains: ' 1 'histoire de l'occasionnalisme ... ne se confondrait pas avec celle des sources du malebranchisme, mais aussi bien, quoique pour d'autres motifs, avec celle d'une postérité sans doute inattendue, comme en témoigne la transposition berkeleyanne'. See also Charles 2004, 73-88; Fritz 1954, 572; Lee 2012, 575; Downing 2005, 209; Hight 2017, 198-99, nn. 2-4. Sukjae Lee clearly argues for Berkeley's occasionalism whilst discerning it from Malebranche's one, whereas Lisa Downing and Marc Hight call for Berkeley's semi-occasionalism in the sense that God is the sole true cause of bodies for finite minds in the physical realm but their volitions are not powerless in the spiritual realm. However, this article does not have enough room for discussing all sorts of occasionalist interpretation (Lee and other recent commentators).

9 More explicitly than with the ontological theory of occasionalism, Berkeley disagrees with Malebranche's epistemological theory of vision in God. Against 'the enthusiasm of Malebranche', Berkeley, in the person of Philonous, argues in Dialogues 2:214: 'in truth I am very remote from it. [Malebranche] builds on the most abstract general ideas, which I entirely disclaim. ... I entirely agree with what the holy Scripture saith, that in God we live and move and have our being.' The italics (original emphasis) here, or the Pauline doctrine about our causal dependence on God, is Berkeley's quote of Acts 17:28. The rest of the verse shows St Paul's quote of the Stoic poet Aratus' Phaenomena, verse 5: 'For we are also his offspring' (KJV). Besides this Dialogues 2:214, one can find the same quote in e.g. Principles 66, 149; Dialogues 3:236; Alciphron 4:14; Guardian Essay no. 88 ('The Christian Idea of God', Works VII, 219); The Theory of Vision Vindicated and Explained $\S 2$ (Works I); Notebooks 827. From the fact that both Malebranche and Berkeley often quote the italics part, A.A. Luce infers that Berkeley can 'agree with that part of Malebranche's philosophy'. Luce goes on to argue that Malebranche's Search formed Berkeley's metaphysical system of immaterialism (1967, 83; Principles 6). Here I do not side with Luce, whereas, when they frequently quote Acts 17:28, I think both Berkeley and Malebranche might have realised the Stoic essence in this verse. On the possible Stoic influence upon Berkeley's philosophy, see Daniel 2001, 179, nn. 1-3; 2008, 207-09, 215, 228, n. 30.

10 Malebranche 1997, 448 (The Search after Truth, VI, pt. 2, ch. 3). 
This indicates that created beings cannot cause their actions for themselves without God's causal, volitional power, which I take as the divine efficient cause. Thus, creaturely volitions are occasional causes for God that truly brings about the efficacy of motions. Put another way, occasionalism regards the wills of creatures as occasions for God to act. When God is the first and sole cause for us, we ourselves cannot be secondary causes but only the occasional causes for divine operation.

Berkeley considers these features of occasionalism in Principles 53. Whilst not explicitly mentioning Malebranche here, Berkeley criticises 'some of the Schoolmen' and 'modern philosophers' for their 'very unaccountable and extravagant supposition', even 'though we should allow it possible'. Malebranchean occasionalism can be implied as one of the modern philosophers. The occasionalist 'supposition' of them could be formulated in Berkeley's argument: ${ }^{11}$

(1) matter exists, but is causally inert or inactive, for 'there are no corporeal causes'. ${ }^{12}$

(2) none but God has the power or activity for 'producing any one effect in Nature'.

(3) matter is a sole, immediate occasion (i.e. occasional cause) for the divine 'power or activity'.

Therefore,

(4) matter is merely an occasional cause (not the real cause), on which occasion God acts as 'the immediate efficient cause of all things'. (Principles 53)

In this occasional causation or occasionalism, the conclusion (4) follows the three premises at least. The conclusion highlights the passivity of matter existing in nature (premise 1), since corporeal beings are merely occasional causes for God's efficient omnipotence (premises 2-3). It may be suggested that Berkeley rejected the second premise as regards the divine sole cause. However, only if all that exist are matter and God does the second premise follow from the first one. The point is Berkeley's disclaimer specifically against the first premise, and the occasionalist con-

11 See also Richmond 2009, 90.

12 See the first mention of matter in the Principles: 'the very notion of what is called matter ... involves a contradiction in it' (Principles 9). On the analysis of defective conditions of 'matter' as the object of all cognition in Berkeley's system, see e.g. Ferrier 2001, 397-99, 489-92; Keefe 2007, 103. See also De motu 71: 'second corporeal causes ought to be understood, no account being taken of the actual seat of the forces or of the active powers or of the real cause in which they are.' Douglas Jesseph regards this part not allowing for any active power or real cause of matter, as 'very similar to the occasionalist thesis' $(1992,106$, n. 46). 
clusion therefrom. It is clear, therefore, that Berkeley tried to avoid the connection to the doctrine of occasionalism in his immaterialist system.

Nonetheless, despite the criticism of his precursors' occasionalist supposition, a number of commentators take Berkeley to be an occasionalist. For instance, Nicholas Jolley argues that: ${ }^{13}$

even in his mature philosophy, Berkeley remains something of an occasionalist; although he no longer holds that finite spirits are impotent, at least with respect to physical processes (my emphasis) Berkeley continues to teach that true causality must be ascribed to God alone.

As for the processes of bodily motions, Jolley here claims that Berkeley's argument is ultimately occasionalist, even though Berkeley would not qualify it. This is because God is the single true cause in the motion of human bodies, such that Berkeley appears to be held 'in the grip of a Malebranchean argument' ${ }^{14}$ One's volitional acts are merely the occasional causes of the intended bodily motions, on which occasions God solely and really operates his causal omnipotence on one's body. ${ }^{15}$ Therefore, Jolley builds his reading on this passage below about the causal dependence of one's will on God, in Principles 29:

whatever power I may have over my own thoughts, I find the ideas actually perceived by sense have not a like dependence on my will (my emphasis). When in broad day-light I open my eyes, it is not in my power to choose whether I shall see or no (my emphasis), ... There is therefore some other will or spirit that produces them.

Here one needs to read with care the distinction between perception and motion in bodies. Properly speaking, the (sense) perception is a passive reception of ideas that occurs whether or not one wills, intends, or wishes to perceive. For instance, depending on the weather changing, the eye perceiving the day light outside is not necessarily related to one's will to do so. This is because, according to Jolley, the sensory ideas are causally independent of one's volitional power. ${ }^{16}$ Whereas the motion in body parts, putting aside some automatic reflex action (e.g. knee jerking), is directly caused by the will or volitional power (e.g. moving legs

13 Jolley 1990, 230. On a similar interpretation, see Pitcher 1981, 221-27. In support of Berkeley's 'unqualified occasionalism' (Jolley 1990, 232), given his mentions of 'occasional causes' as signs, Jolley references Principles 31, 65; Correspondence 1729:2. On the other hand, Jolley bewares of non-occasionalist points on one's volitional power of moving one's limbs in De motu 25; Siris 161. I will treat the latter citations in §III.

14 Jolley 1990, 230.

15 Jolley $(1990,233)$ here sides with Taylor $(1985,222)$.

16 Jolley 1990, 233; Principles 29. 
to walk outside, be it in the dark or in the day light). ${ }^{17}$ However, it is not the case when the physical motion is restricted by the initial sense perception (e.g. because of too dark a room, one cannot see without any light and therefore not freely walk inside). Then, it can be read in the above passage that, independent of the will of one's mind, 'some other will or spirit', namely God, exercises one's sense perception and the following physical motion. ${ }^{18}$ On the occasionalist reading like Jolley's, our human wills could be merely regarded as the occasional causes for God's operation in the human perception and bodily motion.

Secondly, C.C.W. Taylor also reads Berkeley as claiming that physical motion is not caused by one's own but by God's volitional power. In fact, in the standard reading of Berkeley's philosophy of action, one can find the association with occasionalism from many commentators' arguments. This is what Taylor calls 'the occasionalist theory of volitions', irrespective of Berkeley's argument against occasionalism. ${ }^{19}$ According to Taylor, one's volitions act as if 'petitions, expressive of desires which we ourselves are powerless to put into effect, but which God in his goodness actualises on our behalf' ${ }^{20}$ As for this divine occasionalism, to which Berkeley seems to be reverted, I reconstruct Taylor's argument as follows: ${ }^{21}$

(1) 'the ideas imprinted on the senses are not creatures of my will', such that we have no causal power over them. (Principles 29)

(2) the real world is composed of the ideas that appear to our minds through the senses. (Principles 33-34)

(3) our minds have, by exercising the will, no causal power over the ideas of the real world. (from 1-2)

However,

(4) 'I find I can excite ideas in my mind at pleasure, and vary and shift the scene ... It is no more than willing, and straightway this or that idea arises in my fancy.' (Principles 28)

Therefore,

(5) despite the internal activity of the will (mental faculties at will), we are impotent in the external, real realm. (from 3-4)

17 In Berkeley's subtle definition, the mind/spirit/soul/oneself is the will as a power; it is not directly the volition as an act. See e.g. Notebooks 478a, 621, 699, 849; Principles 2; Dialogues 3:240; Correspondence 1729:2.

18 See also Principles 148: 'whithersoever we direct our view, we do at all times and in all places perceive manifest tokens of the divinity: everything we see, hear, feel, or any wise perceive by sense, being a sign or effect of the Power of God; as is our perception of those very motions, which are produced by men.'

19 Taylor $(1985,222)$ particularly considers occasionalism in Berkeley from Dialogues 2:220; Principles 68-72.

20 Taylor 1985, 222-23.

21 Taylor 1985, 213. 
In the above reconstruction, also given God as the only cause of bodily motions, the occasionalist reading can be inferred: i.e. no external or real movements are caused by human minds. In this Berkeleian world of ideas perceived by the senses, as Taylor concludes, 'we are made for action, but condemned to inaction'. ${ }^{22}$ For one can but presuppose the other will, or the divine one, to ensure the perception of ideas in the external realm. The controlling state of the will is limited to one's internal imagination and thought, to the extent to which the human mind can invoke ideas at pleasure or at one's disposal. In this occasionalist key, thus, the wills of finite minds are inefficacious for exciting or causing ideas of the intended physical motions.

As is clear in Taylor's argument, it is important to interpret the relationship between willing minds and perceived ideas in terms of voluntary motion. On the occasionalist reading, not until human minds (or spirits) depend on the divine omnipotence can their intended physical changes be fully explained as real, or as perceived ideas, in the outside world. As shown in Principles 147:23

There is not any one mark that denotes a man, or effect produced by him, which doth not more strongly evince the being of that spirit who is the Author of Nature.... He alone it is who upholding all things by the Word of his Power, maintains that intercourse between spirits, whereby they are able to perceive the existence of each other.

This suggests that the natural or human world is upheld or sustained by the divine power so that we can consistently perceive the ideas of things and actions, including our physical motions. ${ }^{24}$ Therefore, only by the sustenance of God (or 'the Word of his Power') does 'that intercourse between spirits' lead to the perception of each other's existence. On the other hand, simultaneously, Taylor warns us of a theological challenge of occasionalism, in cases where the Author of Nature may bring about sinful bodily motions. ${ }^{25}$ Theologically, one cannot claim that God should force us to commit sin. Here Taylor argues that Berkeley does not sufficiently resolve this problem, for the occasionalist framework is prone to be undermined by ascribing human guilty causes to God. Whilst I will later consider this problem in theodicy, Taylor regards Berkeley as an occasionalist so as to answer why human wills are in-

22 Taylor 1985, 225.

23 Taylor 1985, 220. See also Principles 150.

24 See also Lee 2012, 551-552; Principles 34: 'All things that exist, exist only in the mind, that is, they are purely notional. What therefore becomes of the sun, moon, and stars? What must we think of houses, rivers, mountains, trees, stones; nay, even of our own bodies?' (Lee's and my emphases)

25 Taylor 1985, 223; Dialogues 3:236-237; Correspondence 1729:2. 
ert in invoking real ideas in the external realm. Indeed, but for God's causal power, as Berkeley states, 'no point in physics is explained ... nor is it conceivable'. ${ }^{26}$

Finally, in the light of volitional impotence of human minds, Jonathan Bennett similarly finds a version of occasionalism in Berkeley. Bennett carefully examines Dialogue 2:220 where Berkeley (his mouthpiece Philonous) argues for God's causal power that makes the human mind perceive ideas: ${ }^{27}$

I only ask whether the order and regularity observable in the series of our ideas, or the course of nature, be not sufficiently accounted for by the wisdom and power of God; and whether it doth not derogate from those attributes to suppose he is influenced, directed or put in mind when and what he is to act, by any unthinking substance.

On Bennett's reading of this passage, Berkeley theologically utilises the doctrine of occasionalism as one of the solutions to argue against materialism of 'any unthinking substance' ${ }^{28}$ In this context, God alone can orderly and regularly maintain the course of nature composed of ideas, whereas thinking that we humans do instead of God would 'derogate from' the divinity. This reading amounts to occasionalism, in the sense that all ideas that our minds have are brought about only by the divine mind. There, in defence of Berkeley's own immaterialism, occasionalism might answer why ideas of bodily motions, not matters per se, are caused by the divine power. Despite Berkeley's criticism of his precursors' occasionalist supposition (Principles 53), according to Bennett, Principles 67-72 also confirm that there are no extra-mental 'occasions' for inert and passive matters, for only the ideas can exist in the mind.

Certainly, Bennett agrees with the existence of our will but denies that our mental, volitional acts are the causes of bodily motions. According to him, it is 'a gift from God' so as to enjoy one's voluntary movements of body parts, and therefore: ${ }^{29}$

Berkeley, it seems, must conclude that when I voluntarily clench my fist, I actively perform a mental act - a volition - and that the rest of what happens falls outside the scope of my activity. That would imply that the modest claim that 'We move our legs our selves' (Notebooks 548) is wrong (my emphasis): we do not move our legs; rather, we will that our legs should move, and then, usually, our legs move.

26 Correspondence 1729:2.

27 Bennett 2001, 141-142.

28 Bennett 2001, 142.

29 Bennett 2001, 166. 
From here one can see Bennett arguing that, even though we humans will that the moving of our limbs shall happen, nothing but God can bring about our voluntary movements that are the divine gift. In other words, no matter how we will to move our body parts, our acts of volition are occasionalistically inefficacious for the occurrence of any ideas of bodily movements. Thus, the wills of human minds are merely the occasional causes for God to actually cause the movements, on behalf of ourselves.

To conclude, one might concur with Jolley, Taylor, and Bennett that, for Berkeley, the human mind cannot realise one's volition to move body parts in the external or real realm. Putting aside one's chimeric (non-real) imagination in the internal realm, the occasionalist reading is possible to the effect that our minds are voluntarily inefficacious as the occasional causes. Thus, on occasions of the wills of our minds, God solely causes real ideas of our physical motions. But the question at issue is whether Berkeley really denies our own mental, volitional power in causing bodily motions. Now, another type of reading of voluntary motion without reference to occasionalism is worth reviewing.

\section{Conservationism}

On another reading of Berkeley, one's volition is deemed not occasionalist or an occasion for God's causal, volitional power. In other words, this reading shows that one could positively have a genuine causal power to move body parts at will, at pleasure, or at one's necessary disposal. I label this alternative reading 'conservationism', the realism about one's immediate volitional cause under the divine conservation. That is, human minds are causally independent of God's omnipotence in bringing about ideas of their own motions, yet under the dependence on God. ${ }^{30}$ This reading, therefore, sheds more light upon Berkeley's theory of action, interpreting bodily motions as the immanent and direct effects or ideas by one's acts of volition. In this second section, I will explain three commentators' views towards the non-occasionalist or conservationist reading.

Firstly, John Roberts objects to the occasionalist reading that negates one's own voluntary motion. ${ }^{31}$ His objection is not that the reading is entirely false, but he is rather sceptical about the compatibility

30 The problem of causal independence of and dependence on God should be carefully discussed, whilst this article delves into the former independence case as realism or (mere) conservationism.

31 Roberts $(2010,412$, n. 3) labels the reading inclined to occasionalism (of Jolley, Taylor, and Bennett) as 'the Standard Interpretation' that contains the problem of our voluntary motions in body parts, from e.g. Notebooks 107 ('unperformed wills, these having no power at all'), 548; Principles 29 (see Taylor's argument in §I). 
between Berkeley's theory of action and the doctrine of occasionalism. ${ }^{32}$ For Berkeley seems to claim that our volitional acts bring something about in the external world. 'To say ye Will is a power. Volition is an act. This is idem per idem' (Notebooks 621). To this extent, Roberts construes that Berkeley takes the power of will to be the activity of volition in the case of human minds, finite or 'limited and dependent' beings (Dialogues 3:240-41). ${ }^{33}$ From here, differing from the occasionalist reading, one could infer that the volitional power of one's mind is to actively bring about ideas of bodily movements within one's limit given by God. For instance, one can usually walk because God gave the proper ability within the limit of human activity, but one cannot fly because God did not give that ability.

Then, Roberts shows an alternative to the standard occasionalist reading of voluntary motion. His reading primarily stems from the interpretation of Berkeley's key sentences in his early notebooks (1707-08) that attract (and bother) commentators. That is Notebooks 548:

S. We move our Legs our selves. 'tis we that will their movement. Herein I differ from Malebranch.

Even if not his official view due to the unpublished Notebooks, Berkeley here clearly draws the line between his and Malebranche's views of voluntary motion. ${ }^{34}$ Berkeley contradicts the occasionalist perspective in arguing that humans do will and thereby move their body parts, e.g. legs and fingers.

On this point, Roberts argues that the will does not strictly have the power to produce 'motion', but merely 'action' as the volition in one's immanent acts. ${ }^{35}$ For he considers Berkeley's point that 'motion being allowed to be no action', one cannot 'conceive any action besides volition' (Dialogues 2:217). ${ }^{36}$ Following Roberts' reading, then, the human will seems to immanently bear the causal power to generate one's action, even if one may not properly perceive the entailing bodily motion. To that effect, however, it is not necessary to assume occasionalism in Berkeley's

32 Roberts 2007, 111-23; 2010, 413.

33 Roberts 2007, 107; 2010, 414, 430; Notebooks 478a, 637, 791 ('I am eternally, constantly willing, my acquiescing in the present State is willing'); Principles 89 (minds/ spirits are 'active, indivisible, incorruptible substances').

34 Malebranche, by contrast, does not take the human 'immanent power' of volition as anything powerful. See Roberts 2010, 415, 419-422; Malebranche 1997, 551 ('Elucidation One' of The Search): 'All we do is stop and rest ... by an immanent act that produces nothing material in our substance.'

${ }_{35}$ Roberts 2010, 415, 419.

36 Roberts 2010, 415-416; Correspondence 1729:4 ('all guilt is in the will'); Dialogues 3:236-237, Alciphron 7:19. 
treatment of the creaturely movements in their body parts insofar as performing the acts of volition.

Secondly, Tom Stoneham discusses Berkeley's view of voluntary motion, primarily from a non-occasionalist or conservationist perspective. For his own thesis, Stoneham claims for Berkeley's 'causal-volitional realism about action' from e.g. Notebooks 548, Principles 145-46, Dialogues 1:196, 3:237, De motu 25. ${ }^{37}$ By this realism, Stoneham indicates that our embodied actions by moving body parts are real or essentially independent of divine mind, so that human minds are causally and volitionally responsible for their actions. ${ }^{38}$ In this regard, pace Stoneham (and also Roberts), it might be circular to state that one's volition causes the embodied action, if the volition is defined in terms of its action. ${ }^{39}$ This realist account of volitional embodiment or mind-body causation, therefore, might require a more logical reinforcement of the connection between volition and action in Berkeley.

Nonetheless, Stoneham does not decisively take this realism, or what I mean by conservationism, as the single available option in view of the historical Berkeley. He admits another possibility that God might be responsible for all the movements in bodies, from e.g. Principles 30 , Dialogues 2:212-14, De motu 34. Thus, whilst he finds realism 'philosophically interesting as a version of immaterialism', Stoneham does not discard other interpretations such as occasionalism (viz. no causal power for human minds) and concurrentism (viz. causal co-operation or compatibilism between divine and human minds). ${ }^{40}$ Yet, between the

37 Stoneham forthcoming, 2-10.

38 According to Stoneham (forthcoming, 1-2, nn. 1-2; 2002, 40-41), Berkeley's realism (conservationism) about action is also based on his realism about sensible qualities or ideas (e.g. pains), the existence of which he cannot empirically doubt (i.e. anti-sceptic). Although they are mind-dependent, except for imagination (chimeric non-reality), 'sensible things ... depend not on my thought' (Dialogues 2:212). Then, to the extent that sense experience in one's mind is realistic, one's action through the embodiment is also realistic, because 'We are chained to a body, that is to say, our perceptions are connected with corporeal motions' (Dialogues 3:241).

39 I very much thank Richard Brook for pointing out this circular problem (and for much more criticism) in the earlier draft.

40 On the division of labour between the divine and creaturely causes in co-operating/concurring in their production, see e.g. Principles 66, 145. On the concurrentist reading alternative to the standard occasionalist one, see note 4 above; McDonough 2008, 572-580; Baier 1977, 391-395; Dancy 1998, 56. In his introduction to Principles, Dancy suggests the possibility of joint agency which is virtually concurrentism, or 'the idea that God combines with us so that together we can do what neither of us could have done alone'. On the other hand, Baier concedes that her account of the concurrent movement that 'divine and human intenders could work together without sharing purposes or goals would be deeply repugnant to Berkeley's religious instincts' $(1977,394)$. But according to Stoneham, the concurrentist reading stands 'against occasionalism, and thus can equally be wheeled out by the realist' or (mere) 
two interpretations of occasionalism and realism, he assesses that 'each has its own costs ... Berkeley the anti-atheist would have been attracted by occasionalism and Berkeley the anti-sceptic by realism' ${ }^{41}$ Admittedly, there might be no fixed consensus on this issue of voluntary motion. ${ }^{42}$

The above reservation notwithstanding, Stoneham points out two compelling reasons for favouring conservationism over occasionalism: (i) Berkeley's theodicy, and (ii) his account of other minds/spirits. ${ }^{43} \mathrm{On}$ theodicy, defending God's immediate cause/action of all actions against sin, Berkeley (as Philonous) argues in Dialogues 3:237:

I have no where said that God is the only agent who produces all the motions in bodies (my emphasis). It is true, I have denied there are any other agents beside spirits: but this is very consistent with allowing to thinking rational beings, in the production of motions, the use of limited powers (my emphasis), ultimately indeed derived from God, but immediately under the direction of their own wills, which is sufficient to entitle them to all the guilt of their actions.

This captures the point on our own agency that produces motions in bodies. For Berkeley considers that God bestows 'limited powers' to human finite spirits or agents, by attributing the causes of all sinful actions (stemming from 'motions in bodies') to our own wills. ${ }^{44}$ Therefore, Stoneham dismisses the possibility of occasionalism on this point. That is, for the sake of theodicy, human minds are not necessarily the occasional causes, but sufficiently the real causes to be liable for sinful actions. Berkeley recognises our own sin and, thus, such a deed (e.g. gluttony by willing to eat too much).

Moreover, on account of knowledge of other minds, the movements of one's body parts or limbs are not simply restricted within one's own perception. The impressions of one's actions can extend to someone else's experience of perceiving (e.g. visualising) them. For example, to

conservationist (forthcoming, 4). In this sense, I assume that the conservationist reading sufficiently subsumes concurrentism but embraces more than that, for it is not necessarily a concurrent causation with God when 'our mind at will can stir and stay the movements of our limbs' as the 'principle of motion' (De motu 25).

41 Stoneham forthcoming, 2, n. 4.

42 As Stoneham (forthcoming, 25) and many commentators mention, if we were able to read Part II of the Principles of Human Knowledge on the free will problem of human (and divine) minds, the scholarly consensus on voluntary motion would radically change. But Berkeley (accidentally) lost the manuscript of Part II in Italy, and never wrote it up again. On his planning of a series of Principles, see e.g. Notebooks 508: 'Mo. The 2 great Principles of Morality. the Being of a God \& the Freedom of Man: these to be handled in the beginning of the Second Book.'

43 Stoneham 2002, 178-214; 2010, 498-501; forthcoming.

44 See also Falkenstein 1990, 435-436. 
see someone walking in front of me suggests that it is that person, not God somewhere, who directly influences my perception of the idea of the person's walking. This point may appear to beg the question for an occasionalist, for in the occasionalist reality it is always God that brings about one's perception. Nevertheless, by moving our own limbs, our minds intend and in effect cause the impressions that the other human minds can have. As in Principles 147:

For it is evident that in affecting other persons, the will of man hath no other object, than barely the motion of the limbs of his body (my emphasis); but that such a motion should be attended by, or excite any other (Stoneham's addition $)^{45}$ idea in the mind of another, depends wholly on the will of the Creator. ${ }^{46}$

The context of this passage (partly cited in Taylor's argument in §I) is explaining why the existence of God, or the Author of Nature, is more evidently perceived than that of human agents. If only focusing on the last sentence, it prima facie suggests that our bodily motions in sense perception are entirely dependent on God's will and acts of volition. However, according to Stoneham, under the condition of divine sustenance of human actions, one's volition of bodily motions (e.g. willing to kick a man by raising one's leg) is causally influential in exciting the perceived ideas of another person's mind (e.g. the pain in the man's body). ${ }^{47}$ In altering someone's sense modalities, one can observe in the course of nature that it is not God but a human particular agent that generates a congeries of ideas about physical motions. Otherwise, we may expect divine miracles in perception, but Berkeley does not assume them between human minds. Hence, for these two reasons-(i) theodicy and (ii) affecting the mind of another-in Stoneham's reading of causal-volitional realism, one's volitional acts for physical motions are not occasionalist in Berkeley.

Finally, Patrick Fleming offers another conservationist reading similar to that of Stoneham. Certainly, Fleming objects to the association of occasionalism with Berkeley's metaphysics. But he does recognise

45 Stoneham 2010, 500. On another interpretation (i.e. without the addition of 'other') of Principles 147, or the perception of one's body within only oneself, see Ayers 1970, 96.

46 The remainder of Principles 147 is also quoted in Taylor's argument in §I above.

47 Stoneham $(2010,501)$ infers in the following, supposing that 'I form the volition to raise my arm (something I know I have the power to do). The effect of this volition will be my arm rising. My arm rising is just a series of ideas. Some of these ideas are perceived by me, and some are perceived by others. So, by directly causing my arm to rise, I have directly caused other people to perceive certain ideas.' 
that God is interpreted as the 'sole and immediate' cause of all the matters including human body parts by pointing to Berkeley's remarks: ${ }^{48}$

In [the Holy Scriptures] God is represented as the sole and immediate Author of all those effects, which some heathens and philosophers are wont to ascribe to Nature, matter, fate, or the like unthinking principle. (Dialogues 3:236)

For in whom we live and move and have our being. (Acts 17:28 in Dialogues 3:236 etc.)

The latter quote is the so-called Pauline doctrine that Bishop Berkeley often quotes. ${ }^{49}$ Both of these biblical remarks, in effect, lead to no causal necessity of human active agents in bringing about ideas of bodily motions. ${ }^{50}$ After all, one may still read the bishop's commitment to occasionalism.

Fleming, nonetheless, argues that it may be philosophically superficial to deem God to be the only agent for physical movements. Rather, Berkeley seems to regard human (inferior and improper) agency as being compatible with the superior and proper agency of God as the creator and sustainer of the material world. ${ }^{51}$ Under this condition, Fleming affirms that humans do act for themselves, as Berkeley states that the human will has 'no other object, than barely the motion of the limbs of his body' (Principles 147)..$^{52}$ Fleming thus claims that: ${ }^{53}$

On Berkeley's account man exercises his will and, under proper (my emphasis) conditions, God makes sure the object of the willing is noticed by other agents properly placed to be affected by it. ... God is the sustainer of the world; He maintains causal laws that insure humans can act (my emphasis); He sets down these laws at the moment of creation, which is compatible with allowing humans the ability to act.

Accordingly, Fleming construes the human acts of volition as compatible with God's proper sustenance of causal laws of nature, which en-

48 Fleming 2006, 416-417.

49 See note 9 above, on the bishop's number of citations of the Pauline doctrine.

50 See also Siris 257: 'The true inference is that the self-thinking individual, or human person, is not the real author of those natural motions. And, in fact, no man blames himself if they are wrong, or values himself if they are right.'

51 By this compatibility between God and human agency, Fleming $(2006,416-417)$ does not infer concurrentism between the minds of God and humans.

52 Fleming 2006, 419. Mentioning the other textual evidence, e.g. Principles 33, 148; Dialogues 2:218-219, 3:237, Fleming was cautious where 'Berkeley uses the language of action without discussing agency' (2006, n. 15).

53 Fleming 2006, 416, 420, n. 18. 
sures and enables human bodily movements. It may be observed that Fleming's claim for God's (mere) conservation of the world as the 'causal laws that insure humans can act' requires the more rigorous textual evidence in Berkeley, with regard to the extent to which the divine laws of nature cover voluntary motions by human minds. However, given the divine sustenance, Fleming's argument for the creaturely voluntary motion under the divine conservation augments Stoneham's reading and citations. ${ }^{54}$ In the next section, I will further bear in mind Fleming's criticism of the occasionalist reading.

Thus far, I reviewed that the alternative conservationist reading could critically differ from the standard occasionalist one, in acknowledging (ideas of) physical motions caused by finite minds under the divine maintenance. Concurring with Stoneham, Fleming, and even Roberts, I will champion the conservationist interpretation of Berkeley's view of voluntary motion by the human mind. For this purpose, the next and final section shows my evaluation of the two types of reading of Berkeley's consistent position.

\section{Evaluation}

Could one, in the end, award the palm to either of the two readings: occasionalism, on the one hand, and non-occasionalism in the sense of conservationism, on the other? The two readings could offer different interpretative rewards, but each at some cost. ${ }^{55}$ In this final section, I will evaluate why the conservationist reading offers the greater philosophical merit than the occasionalist one. For this aim, I will structure my argument in three steps: putting forward 1 . why I disagree with the occasionalist reading, 2. why I endorse the conservationist reading, and 3. how my reading develops and reinforces the latter conservationist reading by considering the faculty of willing in a finite mind as its principle. ${ }^{56}$

54 As for Berkeley's theodicy or problem of evil, Fleming and Stoneham converge on Dialogues 3:237, where Berkeley attributes 'all the guilt of their actions' to the immediate human volitions. See Fleming 2006, 427; Stoneham's point (i) above; Correspondence 1729:4.

55 See also Stoneham forthcoming, 2. As to why I do not consider the concurrentist reading, see notes 4 and 40 above.

56 In terms of a faculty of willing, in Berkeley's sense, it cannot be abstracted nor distinguished from one's notion or self-knowledge through reflection. See e.g. Alciphron 7:5, 7:18, 7:21 ('such terms as power, faculty, act, determination, indifference, freedom, necessity, and the like ... stood for distinct abstract ideas: and that this supposition seems to ensnare the mind into the same perplexities and errors, ... I am conscious that I am an active being, who can and do determine myself'); note 17 above; Harris 2010, 342-43, 348; Grzeliński 2017, 188-190. James Harris then stresses that the self-consciousness as willing or volition is 'not to be understood as awareness of an 
Firstly, I will account for my disagreement with the occasionalist reading. The occasionalist reading does involve a cost of its interpretation. According to Christian belief (as Berkeley was an Anglican Bishop), human beings are sinners by nature, to the effect that doctrines of Incarnation and Atonement are required. ${ }^{57}$ But simultaneously, humans are the proper subjects of moral judgement, lest God be the author of our evil, sinful bodily motions. From the point of Christian theodicy, as Taylor and others worry, it is impossible for Berkeley to accept the necessity that God should cause sinful effects/ideas of physical movements. Rather, as seen in Stoneham's argument in §II, all sins are immediately wrought by the sinner's will or human agency (Dialogues 3:237). It is true, the historical occasionalists, Malebranche included, actually prevented this problem in theodicy. ${ }^{58}$ But Berkeley tried to detach his theological metaphysics from his interpretation of occasionalism of his precursors (Principles 53, 67-72; Dialogues 3:236-237). In the light to theodicy, therefore, the occasionalist reading does not offer the textual affinity with Berkeley's view of sinful voluntary motion.

Furthermore, as for the cost of occasionalism, the case is not only about sinful actions, but also about natural events composed of human bodily motions. On this point, Fleming criticises Taylor's occasionalist reading. ${ }^{59}$ Siding with Fleming, I think that Taylor problematically assumed that Berkeley's metaphysics 'allows no role whatever for human agency' from the reasoning that humans 'are absolute in the internal realm, impotent in the external realm'. ${ }^{60}$ As I reconstructed Taylor's internal-external distinction of human volition (from Principles 28-34) in §I, his version of Berkeley cannot afford humans' own moving of body parts in the external world. In fact, not charitably, Taylor's argument partially rests on some arguable points in Berkeley. For he refers to these entries of Notebooks: ${ }^{61}$

autonomous power possessed by the will itself' $(2010,350)$. I agree on this point. 'The Will not distinct from Particular volitions' (Notebooks 615), such that my conservationist reading does not regard the will as one's mental faculty generating further volitions but merely as 'the notion of the soul', mind or spirit (Principles 144). In the notion of the human mind, then, I read Berkeley as including the faculty of willing or directing the motions in body parts, whereby an 'embodied' existence of the human mind bears the 'notion of spirit from thought and action' together with the opposed 'notion of body from resistance' (Siris 290).

57 Plantinga 2015, 141-142.

58 The occasionalist Malebranche, in contrast to Berkeley, eschews the problem in theodicy concerning the evil and sinful acts, by appealing to the sinner's particular will without God's general will. See Schmaltz 2017.

59 Fleming 2006, 419-24.

60 Taylor 1985, 211, 213.

61 Taylor 1985, 220, 225. 
+ Strange impotence of men. Man without God. Wretcheder than a stone or tree, he having onely the power to be miserable by his unperformed wills, these having no power at all. (Notebooks 107) ${ }^{62}$

t One idea not the cause of another, one power not the cause of another. The cause of all natural things is onely God. Hence trifling to enquire after second Causes. This Doctrine gives a most suitable idea of the Divinity. (Notebooks 433)

These entries that posit God as the first and single causal power can be indeed congenial to occasionalism, although, in my view, Berkeley kept a distance from it. If this is the case, we must admit that Berkeley appreciates the doctrine of occasionalism as most fitting to the divine function. On the occasionalist reading, he might have held the view that no-one but God can solely bring about the real ideas of one's physical motions. In Notebooks, however, I think that these quotes could be conditioned by the obelus mark $(\dagger)$ at the beginning of entries. ${ }^{63}$ Even if not conventionally treating it as a sign that Berkeley finally rejected, one should be mindful of this mark before deciding if they are his unequivocal claims. Likewise, the occasionalist reading based on those parts of his text could therefore be conditioned, whether Berkeley argued for or against human voluntary motion.

On the other hand, as I also reviewed in §I, Bennett explicitly judged that it was 'wrong' to insist that 'We move our Legs our selves' (Notebooks 548). Bennett explicated the reason: 'we do not move our legs; rather, we will that our legs should move, and then, usually, our legs move' ${ }^{64}$ This account does indicate occasionalism, to the extent that God solely causes one's physical motions on behalf of one's will to cause. But here, I also concur with Fleming's criticism directed to Bennett's occasionalist reading, for the conservationist reading is more textually and philosophically viable. ${ }^{65}$

Secondly, then, I will explain why I favour the conservationist reading in Berkeley that human minds do act for their voluntary motions. This is first textually correct, by underlining Berkeley's points on human

62 This entry is the central objection that Roberts $(2010,423-426)$ tried to resolve, even though the volitional power here appears anaemic (i.e. impotent to move body parts).

63 Some scholars claim that entries with the obelus/dagger/plus mark cannot be rejected and underappreciated in the whole 888 entries of Notebooks in his early 20s (1707-1708). For discussion, see McKim 2005, 65, n. 3; Belfrage 1987, 220, $226-227$.

64 Bennett 2001, 166.

65 Fleming 2006, 426-428. 
voluntary action and physical motion, e.g. 'the will of man hath ... the motion of the limbs of his body' (Principles 147, quoted in §II) ${ }^{66}$

I contend, specifically against Bennett (and so Taylor, Jolley, et al.) that the occasionalist construal cutting one's will and actual bodily movement is not philosophically correct. In other words, pace Bennett, it is not wrong to think that one's volition leads to the intended physical motion under the sustenance of divine agency. On my conservationist reading, even 'though (if we may believe Saint Paul) he be not far from every one of us' (Principles 150; Acts 17:27), God is not supposed to direct and bring about a finite mind's immediate voluntary motion. As Berkeley clearly explains in De motu 25:

our mind at will can stir and stay the movements of our limbs, ... and accordingly the mind can be called, correctly enough, a principle of motion, a particular and subordinate principle (my emphasis) indeed, and one which itself depends on the first and universal principle.

This captures the crucial point that the human mind is deemed a particular principle of motion being subordinate to the divine primary, universal principle. ${ }^{67}$ That is, human minds, as the inferior agents (or principles), can produce effects/ideas of physical motions for themselves. This is achievable under the conditions given by God, the divine first principle or law of nature. ${ }^{68}$ On this point, I take the conservationist reading, because human agents as particular principles of motion have active volitions to directly order and move their body parts (legs, fingers, eyelids, etc.) ${ }^{69}$ insofar as their limited powers are sustained by God.

66 Fleming 2006, 419. Besides Principles 147, Fleming's own reading highlights Principles 33, 148; Dialogues 2:218-219, 3:237.

67 Moreover, Passive Obedience (Works VI) is noteworthy, for Berkeley argues that 'most moral precepts do presuppose some voluntary actions (my emphasis), or pacts of men' (§ 25, see also $\S \S 14,33$ ), even though " "Thou shalt not resist the supreme power" a rule or law of nature' $(\S 15$, see also $\S \S 3,17,53)$. In this moral discourse, human minds are assumed to be obedient or subservient to the divine principles or laws of nature, but I think that Berkeley here does not discard the voluntary motions of human rational agency. For more discussion of moral volitions and actions in Passive Obedience and Alciphron, as the intentional behaviour view (cashing out the volitional component of a volition-behaviour pair), see Frankel 2015, 113. It should be noted that Melissa Frankel does not take a 'conservationist' interpretation for mind-body causation in human moral action, but rather she posits Berkeley somewhere neutral between the 'occasionalist' and 'concurrentist' readings (as long as divine power is always required for human voluntary motion).

68 See Dialogues 2:219: 'We indeed, who are beings of finite powers, are forced to make use of instruments. And the use of an instrument sheweth the agent to be limited by rules of another's [i.e. God's] prescription'.

${ }_{69}$ On active volitions of human minds, see e.g. Notebooks 643; Alciphron 7:8; Harris 2010, 346-348. 
On the contrary, the occasionalist reading reaches an impasse, because it cannot dismantle why Berkeley keeps considering the cases for our inherent and immediate voluntary movements in bodies under God's control.

However, one of the interpretative problems connected with conservationism is, as Annette Baier critiques, that Berkeley fails to provide a sufficient answer to the question of how divine and human volitions (or intentions) and modes of bringing about are interrelated. ${ }^{70}$ Moreover, as Michael Ayers observes, Berkeley fails to clarify the distinction between 'voluntarily imagining one's leg moving' and 'voluntarily moving a leg', because 'in the latter case the ideas that constitute the leg-moving would have to be both voluntary and, being "real", involuntary'. ${ }^{71}$ Should we, then, accuse Berkeley of these philosophical missteps? - I suppose not. It is true that Berkeley does not fully analyse the interactions between divine and human minds, nor does he account for their effects or ideas constructed by their voluntary-involuntary actions. Nonetheless, these do not mean that Berkeley necessarily failed to account for the creaturely voluntary motion (by e.g. jettisoning the completion of Part II of the Principles). ${ }^{72}$

Concerning the cost of the conservationist reading, then, Berkeley's schema of causal relation between divine and human minds may be jeopardised. This is because the conservationist realism cannot signify the extent to which God influences the physical movements by the creaturely immediate acts of volition. ${ }^{73}$ On the standard occasionalist reading (by Jolley, Taylor, Bennett, et al.), by contrast, Berkeley seems to have little problem in this theological respect by taking refuge in the Pauline tenet that 'in God we live and move and have our being' (Acts 17:28). That is, presupposing the entire dependence of human minds on the divine cause, the occasionalist reading does not entail theological errors about the perception of real ideas in the external world. For in this case, it is always God that really brings about ideas of physical motions in the external world.

Nevertheless, away from the association with occasionalism, we could advocate the viability of the conservationist reading that Berkeley kept arguing for voluntary motion by the human mind. In addition to Roberts and Fleming, as reviewed in §II, I agree with Stoneham's (realist) conservationist reading from the two points of view: (i) theodicy and (ii) the account of influencing other minds. From these perspectives, one may be sufficiently able to embrace that reading. However, I think that

\footnotetext{
70 Baier 1977, 413.

71 Ayers 1993, xxxi.

72 See note 42 above.

73 Plantinga 2015, 133-35.
} 
Stoneham's reading is not an all-things-considered argument against occasionalism, for there can be one more important point of view that textually and philosophically reinforces the conservationist reading: (iii) a directing principle stemming from the faculty in the human mind at will. The clue is by analogy between the minds of God and humans. To my knowledge, this point is undervalued in Berkeley literature, but I consider it significant in terms of the necessary principle in human volitional acts.

Thirdly and finally, I will clarify in what way my reading further supports the conservationist reading. This is to answer why humans can will and thereby cause our physical motions within the purview limited by God. From my point of view, (iii) the directing principle of the human willing should be more appreciated. As seen above, De motu 25 explained the very point that the human mind at will (or at one's disposal) was the particular and subordinate principle of physical motion. Here in addition, I delve into specific sections in his later work, Siris (1744). There, Berkeley claims that 'In the human body the mind orders and moves the limbs' (Siris 161). In support of this claim, provided that Berkeley argued for the sake of his own philosophy ${ }^{74}$ my explanatory focus is upon the prior section in Siris:

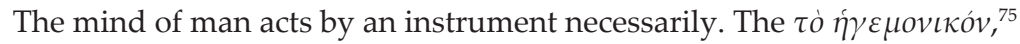
or Mind presiding in the world, acts by an instrument freely. Without instrumental and second causes there could be no regular course of nature. ${ }^{76}$ And without a regular course, nature could never be understood; mankind must always be at a loss, not knowing what to expect, or how to govern themselves, or direct their actions for the obtaining of any end. Therefore in the government of the world physical agents, improperly (my

${ }^{74}$ The degree to which the content of Siris should be regarded as Berkeley's own philosophy may be a problem. On criticism of a unified continuation of Berkeley's metaphysical system from the earlier works up to Siris, see Wilson 1994, 37-39. Berkeley at least had long prepared for the content of Siris, as he stated to his long-term friend Thomas Prior: 'I had of a long time entertained an opinion agreeable to the sentiments of many ancient philosophers, that fire may be regarded as the animal spirit of this visible world' (Four Letters and Farther Thoughts on Tar-water, 'First Letter' § 16, Works V). Thus, I do not think that his long-lasting entertainment of ancient philosophies was independent of the whole of his philosophy, especially in Siris.

75 This is originally the Stoic concept meaning the principle or life and action, the directing faculty or self-power of the divine and human minds, souls, or animate beings. See Baltzly 2018; Hutton 2017, 465-466, 479-481. On Berkeley's positive appreciation for Stoic psychology and cosmology from the earliest Notebooks to the latest (and most bizarre) Siris, see Breuninger 2010, 151; Daniel 2008, 207-219. On the view against mine, i.e. that Berkeley merely reports Stoicism and other ancient theories but shuts his own mouth in Siris, see Jessop, 'Editor's Introduction' in Works V, 16.

${ }^{76}$ Berkeley had held this point on the 'regular course of nature' in Principles 30-31, 62; Jessop, Works V, 84, n. 3. 
emphasis) so called, or mechanical, or second causes, or natural causes, or instruments, are necessary to assist, not the Governor, but the governed. (Siris 160)

From here, one can see Berkeley arguing that the divine mind, as ' $\tau \dot{0}$ i $\gamma \varepsilon \mu$ ovıкó $v^{\prime}$ (meaning 'the hegemony', 'the directing/ruling principle', or 'the commanding faculty'), ${ }^{77}$ is assumed to freely exercise his own instrument (of his created nature) to will or direct the regular natural course. But also, human minds, as the secondary causes, ${ }^{78}$ necessarily use their instruments (or physical agents) to move their body parts in the 'regular course of nature'. Hence, without these two kinds of instrumental causation, we humans are prone to be at a loss, missing 'what to expect, or how to govern themselves'. Furthermore, as we read, the 'Mind' or God infinitely has his free or proper $\eta \gamma \varepsilon \mu$ ov เкóv (directing principle). Besides the divine mind, however, I read that finite minds also make their own 'physical agents' necessarily work ('assist') as their instruments, so that their minds could be their improper version of $\eta \gamma \varepsilon \mu$ ovıкóv. ${ }^{79}$

If my treatment is correct, this improper $\eta \gamma \varepsilon \mu$ ovıкóv can be understood as the human inferior or secondary principle of thinking, deciding, and willing by means of their physical instrumental (mechanical) causes. ${ }^{80}$ This is because Berkeley argues that it is the instrument by means whereof the mind exerts and manifests herself in the motions of the body' (Siris 156). In moving the body parts, therefore, there is

77 See note 75 above.

78 As to the secondary status of finite minds in relation to the divine first cause, I do not read concurrentism because the 'instrumental and second causes' of physical agents that human minds direct are 'necessary to assist' themselves or 'the governed' (Siris 160). This does not indicate the scholastic dogma of concurrence between the divine primary cause and creaturely secondary causes, but the creaturely immediate causes by their own instruments under the conservation by the divine free instrument. Also in Siris, there are parallelisms between the 'macrocosm' (the world or universe moved by God) and 'microcosms' (the bodies of humans or living beings). 'Aether' or 'pure fire' works in the macrocosm, whereas 'animal spirits' play the same role in the microcosms. See Moked 1988, 101-103; Wilson 1994, 50; Siris 153-161, 261 (the animal spirit in the human body or microcosm is 'only an instrument of motion, and the instrument not as a help to the Creator, but only as a sign to the creature'), 290 ('the soul of an animal' has 'its body ... as an instrument'), 361 (the trinity of 'Authority, Life, and Light' pervasively conserves the macrocosm and the microcosm).

79 The 'physical agents' in this context indicate the 'animal spirit' in the human bodily microcosm as 'the immediate physical cause of their motion' (Siris 161). See also Siris 87, 166, 261 ('particular voluntary motions to be impressed by the [human] mind on the animal spirit').

80 The instrumental causes directed by human minds in moving bodily animal spirits within themselves can be interpreted as anti-occasionalist (i.e. anti-Malebranchist) as well as non-concurrentist between the divine and creaturely acts of volition. See Moked 1988, 104-105. 
analogy between the human ('governed') mind and divine ('Governor') mind as for their respective principles of directing $\eta \gamma \varepsilon \mu o v \iota k o v{ }^{81}$ In this analogical sense, therefore, the human mental faculty of willing as one's particular directing principle 'orders and moves the limbs' in the acts of volition (Siris 161).

Accordingly, concerning the human volitional activities (including sinful actions in God's eyes), moving one's own body parts depends on the necessary control or self-power of the human mind, even under the governance of the divine mind. As construed from Siris 160-161, this is what Berkeley had consistently argued for the human mind-body causation under the proper sustenance of God, throughout his early to late works. This is why, therefore, I embrace the conservationist reading for the more viable interpretation of Berkeley than the occasionalist reading.

By contrast, the occasionalist reading could not integrate the above Siris interpretation into the occasionalist schema that humans causally depend on God for voluntary motion. From my points of view, those who interpret Berkeley to be an occasionalist (Jolley, Taylor, Bennett, et al.) fail to explain Berkeley's remarks about the human mind having an inferior principle of motion. Their interpretations are rather determinate in requiring no causal faculty to move any bodies for human minds in volitional acts. In accordance with the divine first and proper cause, however, the secondary causes directed by our minds can be operative instrumentally but improperly in our body parts. In other words, the conservationist reading supports the hegemonic role of human wills in bringing about the ideas of moving body parts, given and governed by the divine omnipotence. That is why Berkeley claims that 'thinking rational beings', namely we humans, are 'in the production of motions' by 'the use of limited powers ... immediately under the direction (my emphasis) of their own wills' (Dialogues 3:237). This rather amounts to Berkeley's consistent philosophical standpoint, which one can interpret in the sense of realism regarding the creaturely volitional power for $d i-$ recting the motion in body parts.

To summarise, I specified the respective drawbacks in taking the two readings. As Baier and Ayers pointed out, it is true, Berkeley does not much elaborate on the causation between divine and human minds in willing and bringing about the effects (ideas) of physical motions. Then, the conservationist reading may be undermined when, as creaturely causation, it cannot identify the extent to which God causes real ideas of physical motions for human minds. Whereas the occasionalist reading is more problematic than the conservationist one when, in acts of volition, denying the creaturely secondary causes contradicts the actual (both sinful and natural) motions in the creaturely domain. In the

81 Moked 1988, 103; Siris 156, 161. 
end, I evaluate that the non-occasionalist or conservationist reading is more worthy than the occasionalist one because, from my final perspective, finite minds are supposed to improperly but necessarily direct the motions in body parts at will, or at their disposal, being under the proper conservation of God.

\section{Conclusion}

As a result, I have presented how to critically read Berkeley's text concerning the creaturely voluntary motion in body parts. Despite Berkeley's disclaimer regarding the 'very unaccountable and extravagant supposition' of occasionalism (Principles 53), a number of interpreters still read his view of voluntary motion from an occasionalist perspective, as one's volition is an occasional cause for God that produces the effects (real ideas) of motions. The occasionalist construal may be possible based on his ultimate account of the Pauline doctrine, in God we move (Acts 17:28), since 'God is represented as the sole and immediate Author of all those effects' (Dialogues 3:236). However, Berkeley argued that the human mind had 'no other object, than barely the motion of the limbs of his body', even though everything was being upheld by God (Principles 147).

Hence, differing from the standard reading of Berkeley as an unqualified occasionalist, I have advocated the greater feasibility of the alternative reading that he is a conservationist as regards voluntary motion, for which finite minds should be immediately responsible under the divine conservation. This reading converged upon the three points: (i) theodicy (human volitions, not God, causing sinful actions), (ii) the account of changing the sense modalities of other minds, and (iii) the hegemonic or directing principle stemming from the faculty in the human mind. There being more problems in discussing the relationship between volition, action, and motion in Berkeley, it could be concluded that the conservationist reading is textually and philosophically more tenable than the occasionalist one. ${ }^{82}$

82 The author hereby expresses his gratitude for ungrudging and helpful comments of Richard Brook, Kenneth Pearce, Peter West, Andrea Sangiacomo, Han Thomas Adriaenssen, and the anonymous reviewers for this journal. In addition, the comments of Jennifer Keefe (official commentator of this earlier version), Melissa Frankel, and many other Berkeley scholars (participants) in Margaret Atherton's Milwaukee Berkeley Workshop (October 2018) were pricelessly beneficial. Lastly, as to this American trip, he is deeply indebted to the alumni of Trinity College Dublin for the generosity of their contribution to three sources of funding: the Provost's PhD Project Award, the Graduate Studies Research Travel Fund, and the Trinity Trust Travel Grant Scheme. 


\section{Bibliography}

Ayers, Michael R. "Perception and Action." In Knowledge and Necessity, edited by G.N.A. Vesey, 91-106. London: Macmillan, 1970.

Ayers, Michael R. "Introduction." In George Berkeley: Philosophical Works including the Works of Vision, edited by Michael R. Ayers, xv-xl. London: Everyman, 1993.

Baier, Annette C. "The Intentionality of Intentions." Review of Metaphysics 30, no. 3 (1977): 389-414.

Baltzly, Dirk. "Stoicism". The Stanford Encyclopedia of Philosophy (2018). Accessed 31 December 2018. https://plato.stanford.edu/entries/ stoicism/.

Bardout, Jean-Christophe. "Le modèle occasionnaliste. Emergence et développement, au tournant des XVIIe et XVIIIe siècles". Quaestio 2 (2002): 461-492.

Bennett, Jonathan. Learning from Six Philosophers: Descartes, Spinoza, Leibniz, Locke, Berkeley, Hume, vol. 2. Oxford: Oxford University Press, 2001.

Belfrage, Bertil. "A New Approach to Berkeley's Philosophical Notebooks." In Essays on the Philosophy of George Berkeley, edited by Ernest Sosa, 217-230. Dordrecht: D. Reidel Publishing, 1987.

Berkeley, George. The Works of George Berkeley, Bishop of Cloyne. 9 vols, edited by A.A. Luce \& T.E. Jessop. London: Thomas Nelson \& Sons, 1948-1957.

Berkeley, George. Philosophical Commentaries, edited by G.H. Thomas, with notes by A.A. Luce. Alliance, Ohio: Mount Union College, 1976.

Bracken, Harry. The Early Reception of Berkeley's Immaterialism 1710-1733. The Hague: Martinus Nijhoff, 1965.

Breuninger, Scott. Recovering Bishop Berkeley: Virtue and Society in the Anglo-Irish Context. New York: Palgrave Macmillan, 2010.

Charles, Sébastien. "Berkeley occasionnaliste malgré lui? De la causalité et de la volonté chez Malebranche et Berkeley". In Science et épistémologie selon Berkeley, edited by Sébastien Charles, 73-88. Saint-Nicolas, Québec: Les Presses de l'Université Laval, 2004.

Dancy, Jonathan, ed. A Treatise Concerning the Principles of Human Knowledge, Oxford: Oxford University Press, 1998.

Daniel, Stephen H. "Berkeley's Pantheistic Discourse". International Journal for Philosophy of Religion 49, no. 3 (2001): 179-194.

Daniel, Stephen H. "Berkeley's Stoic Notion of Spiritual Substance". In New Interpretation of Berkeley"s Thought, edited by Stephen H. Daniel, 203-230. Amherst, NY: Humanity Books, 2008.

Downing, Lisa. "Occasionalism and Strict Mechanism: Malebranche, Berkeley, Fontenelle." In Early Modern Philosophy: Mind, Matter, and Metaphysics, edited by Christia Mercer and Eileen O'Neill, 206-230. Oxford: Oxford University Press, 2005.

Ferrier, J.F. Institutes of Metaphysic (3rd ed., 1875). In Philosophical Works of James Frederick Ferrier, vol. 1, with an Introduction by John Haldane. Bristol: Thoemmes Press, 2001. 
Falkenstein, Lorne. "Berkeley's Argument for Other Minds". History of Philosophy Quarterly 7, no. 4 (1990): 431-440.

Fleming, Patrick. "Berkeley"s Immaterialist Account of Action." Journal of the History of Philosophy 44, no. 3 (2006): 415-429.

Frankel, Melissa. "Actions, Behaviours, and Volitions in Berkeley"s Moral Philosophy." In Berkeley Revisited: Moral, Social and Political Philosophy, edited by Sébastien Charles, 99-114. Oxford: Voltaire Foundation, 2015.

Freddoso, Alfred. "Medieval Aristotelianism and the Case against Secondary Causation in Nature." In Divine and Human Action: Essays in the Metaphysics of Theism, edited by Thomas V. Morris, 75-118. Ithaca: Cornell University Press, 1988.

Freddoso, Alfred J. "God's General Concurrence with Secondary Causes: Why Conservation is Not Enough." Philosophical Perspectives 5 (1991): 553-585.

Freddoso, Alfred J. "God's General Concurrence with Secondary Causes: Pitfalls and Prospects." American Catholic Philosophical Quarterly 52 (1994): 131-156.

Fritz, Anita. "Berkeley's Self - Its Origin in Malebranche." Journal of the History of Ideas 15, no. 4 (1954): 554-572.

Frost, Gloria. "Peter Olivi's Rejection of God's Concurrence with Created Causes." British Journal for the History of Philosophy 22, no. 4 (2014): 655-679.

Grzeliński, Adam. "Alciphron; or the Minute Philosopher: Berkeley's Redefinition of Free-Thinking." In The Bloomsbury Companion to Berkeley, edited by Bertil Belfrage and Richard Brook, 174-195. London: Bloomsbury, 2017.

Jesseph, Douglas M., ed. \& trans. De Motu and The Analyst: A Modern Edition, with Introduction and Commentary. Dordrecht: Kluwer, 1992.

Jolley, Nicholas. "Berkeley and Malebranche on Causality and Volition." In Central Themes in Early Modern Philosophy: Essays Presented to Jonathan Bennett, edited by Jan A. Cover \& Mark Klustad, 227-244. Indianapolis: Hackett, 1990.

Harris, James. "Berkeley on the Inward Evidence of Freedom." In Berkeley's Alciphron: English Text and Essays in Interpretation, edited by Laurent Jaffro, Genevieve Brykman \& Claire Schwartz, 341-350. Hildesheim: Georg Olms Verlag, 2010.

Hight, Marc A. "Berkeley's Strange Semi-Occasionalist Mystery: Finite Minds as Causes." In Occasionalism Revisited: New Essays from the Islamic and Western Philosophical Traditions, edited by Nazif Muhtaroglu, 197-218. Dubai: Kalam Research \& Media, 2017.

Hutton, Sarah. "Salving the Phenomena of Mind: Energy, Hegemonikon, and Sympathy in Cudworth." British Journal for the History of Philosophy 25, no. 3 (2017): 465-486. 
Keefe, Jennifer. “The Return to Berkeley." British Journal for the History of Philosophy 15, no. 1 (2007): 101-113.

Lee, Sukjae. "Berkeley on the Activity of Spirits." British Journal for the History of Philosophy 20, no. 3 (2012): 539-576.

Luce, A.A. Berkeley and Malebranche: A Study in the Origins of Berkeley's Thought. London: Clarendon Press, 1967.

Malebranche, Nicolas. The Search after Truth, translated \& edited by Thomas M. Lennon \& Paul J. Olscamp. Cambridge: Cambridge University Press, 1997.

McDonough, Jeffrey K. "Berkeley, Human Agency and Divine Concurrentism." Journal of the History of Philosophy 46, no. 4 (2008): 567-590.

McKim, Robert. "Berkeley"s Notebooks". In The Cambridge Companion to Berkeley, edited by Kenneth P. Winkler, 63-93. Cambridge: Cambridge University Press, 2005.

Moked, Gabriel. Particles and Ideas: Bishop Berkeley's Corpuscularian Philosophy. Oxford: Clarendon Press, 1988.

Pitcher, George. "Berkeley on the Mind's Activity." American Philosophical Quarterly 18, no. 3 (1981): 221-227.

Plantinga, Alvin. "Law, Cause, and Occasionalism." In Reason and Faith: Themes from Richard Swinburne, edited by Michael Bergmann \& Jeffrey E. Brower, 126-144. Oxford: Oxford University Press, 2015.

Richmond, Alasdair. Berkeley's Principles of Human Knowledge: A Reader's Guide. London: Continuum, 2009.

Roberts, John R. A Metaphysics for the Mob: The Philosophy of George Berkeley. Oxford: Oxford University Press, 2007.

Roberts, John R. "'Strange Impotence of Men': Immaterialism, Anaemic Agents, and Immanent Causation." British Journal for the History of Philosophy 18, no. 3 (2010): 411-431.

Schmaltz, Tad M. Descartes on Causation. Oxford: Oxford University Press, 2008.

Schmaltz, Tad M. "Nicolas Malebranche." The Stanford Encyclopedia of Philosophy (2017). Accessed 31 December 2018. https://plato.stanford.edu/ entries/malebranche/.

Stoneham, Tom. Berkeley's World: An Examination of the Three Dialogues. Oxford: Oxford University Press, 2002.

Stoneham, Tom. "Berkeley." In A Companion to the Philosophy of Action, edited by Timothy O"Connor \& Constantine Sandis, 496-504. Oxford: Wiley-Blackwell, 2010.

Stoneham, Tom. "Action, Knowledge and Embodiment in Berkeley and Locke." In Philosophical Accounts of Action from Suarez to Davidson, edited by Constantine Sandis. Oxford: Oxford University Press, forthcoming.

Taylor, C.C.W. "Action and Inaction in Berkeley." In Essays on Berkeley: A Tercentennial Celebration, edited by John Foster \& Howard Robinson, 211-225. Oxford: Clarendon Press, 1985.

Wilson, Catherine, "Berkeley and the Microworld." Archiv für Geschichte der Philosophie 76, no. 1 (1994): 37-64. 


\section{Summary}

A plausible reading of Berkeley's view of voluntary motion is occasionalism; this, however, leads to a specious conclusion against his argument of human action. Differing from an unqualified occasionalist reading, I consider the alternative reading that Berkeley is a conservationist regarding bodily motion by the human mind at will. That is, finite minds (spirits) immediately cause motions in their body parts, albeit under the divine conservation. My argument then comports with the conservationist reading from three perspectives: (i) theodicy that the human mind is held liable for sinful actions; (ii) an account of the human mind influencing other minds; and (iii) an improper but necessary directing principle of the human mind. This article is a stepping stone to grasping why the conservationist reading is more coherent than the occasionalist one.

Keywords: Berkeley, occasionalism, concurrentism, conservationism, volition, action, motion

\section{Streszczenie}

\section{Berkeley o ruchu wolicjonalnym. Podejście konserwacjonistyczne}

Pozornie słuszną interpretacją poglądów Berkeleya na temat ruchu wolicjonalnego jest okazjonalizm, jednakże prowadzi on do błędnych wniosków, które stoją w sprzeczności z jego wyjaśnieniem postępowania człowieka. Przeciwstawiając się ogólnie pojmowanej interpretacji okazjonalistycznej, poddaję pod namysł alternatywne odczytanie, zgodnie z którym odnośnie do poruszania przez człowieka swym ciałem Berkeley jest konserwacjonistą. Oznacza to, że skończony umysł (duch) wywołuje ruch członków swego ciała w sposób bezpośredni, jakkolwiek ruch ten jest zachowywany przez Boga.

Moja argumentacja zgadza się zatem z konserwacjonizmem w trzech aspektach: (i) teodycei, ludzki umysł jest bowiem odpowiedzialny za popełnianie grzechu; (ii) opisu, zgodnie z którym jeden ludzki umysł może wpływać na inny; (iii) niewłaściwej, ale koniecznej reguły nadającej kierunek decyzjom ludzkiego umysłu. Niniejszy artykuł powinien przyczynić się do wyjaśnienia, dlaczego konserwacjonistyczna interpretacja filozofii Berkeleya jest bardziej spójna od okazjonalistycznej.

Słowa kluczowe: Berkeley, okazjonalizm, konkurentyzm, konserwacjonizm, chcenie, działanie, ruch 